\title{
DEVELOPMENT AND VALIDATION OF BIOANALYTICAL RP HPLC METHOD FOR THE ESTIMATION OF METOPROLOL TARTRATE IN RABBIT PLASMA AFTER TRANSDERMAL AND ORAL ADMINISTRATION: APPLICATION IN PHARMACOKINETIC STUDIES
}

\author{
Mithun Bhowmick ${ }^{1}$, Pratibha Bhowmick ${ }^{2}$, Tamizharasi Sengodan ${ }^{1}$, Sivakumar Thangavel $^{1}$ \\ ${ }^{1}$ Nandha College of Pharmacy and Research Institute, Erode, Tamil Nadu, India \\ ${ }^{2}$ Mittal Institute of Pharmacy, Bhopal, Madhya Pradesh, India \\ *Corresponding authore-mail: bhowmick_theyoungscientist@ymail.com
}

Received 02 June 2015; Review Completed 23 June 2015; Accepted 09 July 2015, Available online 15 July 2015

\begin{abstract}
A simple, specific, sensitive and rapid Reverse phase high performance liquid chromatographic (RP-HPLC) method has been developed and validated for the quantification of Metoprolol Tartrate in small volumes of rabbit plasma. The method was further extended for its pharmacokinetic studies in rabbit plasma samples after transdermal and oral administration. Biological sample preparation involving simple extraction with organic solvent, followed by dilution with mobile phase was adopted to eliminate any chromatographic solvent effects. The method was proven to be linear over a plasma concentration range of 20 $\mathrm{ng} / \mathrm{ml}$ to $100 \mathrm{ng} / \mathrm{ml}$ with a mean correlation coefficient of 0.99 . The limit of detection and the limit of quantification of the newly developed method were determined to be $5.8 \mathrm{ng} / \mathrm{mL}$ and $16.1 \mathrm{ng} / \mathrm{mL}$, respectively. The method was successfully applied to assess pharmacokinetic parameters of Metoprolol Tartrate in rabbit plasma and found out the comparative bioavailability of MT following oral and transdermal dosage forms. The developed method was established as a rapid analytical tool in a pharmacokinetic study as it required short retention time, high precision, sensitivity and small volumes of plasma for analysis.
\end{abstract}

Keywords: Metoprolol Tartrate, RP-HPLC, quantification, Rabbit plasma, Pharmacokinetic study, oral, transdermal.

\section{INTRODUCTION}

Metoprolol tartrate (MT) is a selective hydrophilic Bblocking agent for the treatment of mild and moderate hypertension and also for long term management of angina pectoris. MT has a oral bioavailability of only 38 $\%$ due to extensive hepatic first-pass metabolism. In the blood circulating system it is in the first step $12 \%$ protein bound, then rapidly enters the CNS and has moderate lipid solubility. The metabolism of this drug is hepatically (primarly by CYP2D6). The metabolization occurs also mainly in the liver. Approximately $95 \%$ of the drug is excreted renally and less than $5 \%$ of the drug is excreted unchanged in urine. Peak plasma concentrations are achieved after $2-3$ hours. The halflife of the MT is about 3.2 hours, which makes frequent dosing necessary to maintain the therapeutic blood levels of the drug for long-term treatment. ${ }^{1-6}$ Therefore, MT is an ideal drug candidate for transdermal drug delivery. Several methods have been reported for quantification of MT in plasma using high-performance liquid chromatography (HPLC) with UV or fluorescence detection. Many of these methods involve a complex separation step and are non-reproducible. Hence, the purpose of this investigation was to develop a simple, sensitive, selective and reproducible analytical method for the quantitative estimation of MT in a small volume of human plasma. It is also envisaged that this method will be able to provide an efficient solution for pharmacokinetic, bioavailability or bioequivalence studies of MT. This work is performed to ascertain the comparative bioavailability of MT from oral and transdermal dosage forms. $1,7-10$

\section{EXPERIMENTAL}

\section{Methodology}

In the present work a simple, selective, rapid, precise and economical reverse phase HPLC method have been developed for estimation of Metoprolol tatrate in blood plasma.

Table 1: Solubility of Drug in Different Solvents

\begin{tabular}{|c|c|}
\hline SOLVENT & SOLUBILITY \\
\hline Water & Freely soluble \\
\hline $0.1 \mathrm{~N} \mathrm{HCl}$ & Soluble \\
\hline $0.1 \mathrm{~N} \mathrm{NaoH}$ & Insoluble \\
\hline Methanol & Freely soluble \\
\hline Acetonitrile & Soluble \\
\hline Acetate Buffer & Soluble \\
\hline Phosphate Buffer & Soluble \\
\hline
\end{tabular}




\section{Solubility $^{1-2}$}

Solubility of all three drugs was observed by dissolving them in different solvents. (Table 1)

\section{Selection of Precipitating Agent ${ }^{12,13}$}

Selection of precipitation agent is based on the solubility of drug and good protein protein precipitation property. Metoprolol tartrate is soluble in Acetonitrile and having good protein precipitating property so Acetonitrile was selected as the protein precipitation agent.

Selection of Mobile Phase P-13 $^{\text {Pan }}$
Initially to estimate Metoprolol tartrate, numbers of mobile phase in different ratio were tried. A result was shown in (Table 2).

Taking into consideration the system suitability parameter like RT, Tailing factor, No. of theoretical plates and HETP, the mobile phase found to be most suitable for analysis was Acetonitrile: Methanol: 20 $\mathrm{mM}$ Ammonium acetate buffer (pH 5.0) in the ratio of 25:55:20 v/v/v. The mobile phase was filtered through $0.45 \mu$ filter paper to remove particulate matter and then degassed by sonication. Flow rate employed for analysis was $1.0 \mathrm{ml} / \mathrm{min}$.

Table 2: Mobile Phase Selection

\begin{tabular}{|c|c|c|c|}
\hline Mobile Phase & Ratio & Flow rate & Remark \\
\hline Methanol : water & $50: 50 \mathrm{v} / \mathrm{v}$ & $1.0 \mathrm{ml} / \mathrm{min}$ & Peak Not Found \\
\hline Acetonitrile : water & $50: 50 \mathrm{v} / \mathrm{v}$ & $1.0 \mathrm{ml} / \mathrm{min}$ & Peak Not Found \\
\hline Methanol : Acetonitrile & $50: 50 \mathrm{v} / \mathrm{v}$ & $1.0 \mathrm{ml} / \mathrm{min}$ & Peak Not Found \\
\hline $20 \mathrm{mM} \mathrm{KH}_{2} \mathrm{PO}_{4}$ : Acetonitrile (pH Adjust with 4.0 with OPA) & $20: 80 \mathrm{v} / \mathrm{v}$ & $1.0 \mathrm{ml} / \mathrm{min}$ & Poor resolution \\
\hline $20 \mathrm{mM} \mathrm{KH}{ }_{2} \mathrm{PO}_{4}$ : Acetonitrile (pH Adjust with 3.5 with OPA) & $30: 70 \mathrm{v} / \mathrm{v}$ & $1.0 \mathrm{ml} / \mathrm{min}$ & Poor resolution \\
\hline $20 \mathrm{mM}$ Ammonium acetate buffer ( $\mathrm{pH} 5.0)$ & $25: 55: 20 \mathrm{v} / \mathrm{v} / \mathrm{v}$ & $1.0 \mathrm{ml} / \mathrm{min}$ & $\begin{array}{c}\text { Satisfactory } \\
\text { Result }\end{array}$ \\
\hline
\end{tabular}

\section{* Procedure for preparation of mobile phase}

\section{Step-1 preparation of buffer}

$20 \mathrm{mM}$ Ammonium acetate Buffer in $1000 \mathrm{ml}$ of HPLC grade water, sonicated and $\mathrm{pH}$ adjusted to 5 with orthophosphoric acid.

\section{Step-2 preparation of mobile phase}

Mixed 55 volume of acetonitrile, 25 volume of methanol and 20 volume of buffer. Filtered through
$0.45 \mu$ nylon filter in Millipore unit and degassed by sonication.

\section{Selection of Diluent}

Diluent used for preparation of sample were compatible with mobile phase and no significant effect was observed for retention and resolution of analyte. After various trials Acetonitrile: Methanol: $20 \mathrm{mM}$ Ammonium acetate buffer ( $\mathrm{pH}$ 5.0) was used as diluents.

\section{Selection of Separation Variable}

Table 3: Separation Variable

\begin{tabular}{|c|c|}
\hline Variable & Condition \\
\hline Column & $250 \mathrm{~mm} \times 4.60 \mathrm{~mm}$ \\
\hline Dimension. & $5 \mu$ \\
\hline Particle Size & Octadecylsilane $\left(\mathrm{C}_{18}\right)$ \\
\hline Bonded Phase & $25 \%$ \\
\hline Mobile Phase & $55 \%$ \\
\hline Acetonitril & $20 \%$ \\
\hline Methanol & ACN: Methanol: $20 \mathrm{mM} \mathrm{Ammonium}$ \\
\hline Phosphate buffer (pH- 5.0) & Acetate Buffer $\mathrm{pH}-5.0(25: 55: 20 \mathrm{v} / \mathrm{v} / \mathrm{v})$ \\
\hline Diluent & $25{ }^{0} \mathrm{C}$ \\
\hline Flow rate & $20 \mu \mathrm{min}$ \\
\hline Temperature & $274 \mathrm{~nm}$ \\
\hline Sample Size & $10.792 \pm 0.001 \mathrm{~min}$ \\
\hline Detection wavelength & \\
\hline Retention time & \\
\hline
\end{tabular}

1. Preparation of stock solution: Accurately weighed $10 \mathrm{mg}$ of MT was transferred into $50 \mathrm{ml}$ volumetric flasks separately and dissolved in $10 \mathrm{ml}$ of plasma, then (c) 2011-15, JDDT. All Rights Reserved volume was made up to $50 \mathrm{ml}$ with Acetonitrile and vortex it to get complete precipitation of plasma protein. Stand it aside for few minute, precipitate of protein ISSN: 2250-1177
CODEN (USA): JDDTAO 
settled down then collect the supernatant layer. Centrifuge the collected supernatant layer at $6000 \mathrm{rpm}$ for $7 \mathrm{~min}$ at $4^{\circ} \mathrm{C}$ and then filtered by whatmann filter paper (no.41). Concentration of MT was 200 $\mu \mathrm{g} / \mathrm{ml}($ stock- A).

2. Preparation of Sub Stock Solution: $5 \mathrm{ml}$ of solution was taken from stock-A of METO and transferred into $100 \mathrm{ml}$ volumetric flask separately and diluted up to $100 \mathrm{ml}$ with diluent (Mobile phase) to give concentration of $10 \mu \mathrm{g} / \mathrm{ml}$ (Stock-B).

\section{Linearity and Calibration Graph:}

To establish the linearity of analytical method, a series of dilution ranging from $20-100 \mathrm{ng} / \mathrm{ml}$ was prepared. $0.2 \mathrm{ml}, 0.4 \mathrm{ml}, 0.6 \mathrm{ml}, 0.8 \mathrm{ml}$ and $1.0 \mathrm{ml}$ of stock-B was taken separately in $10 \mathrm{ml}$ volumetric flask and volume was made up to $100 \mathrm{ml}$ with (Acetonitrile: Methanol: Ammonium acetate buffer $(\mathrm{pH} 5.0)$. This gives the solutions of $20 \mathrm{ng} / \mathrm{ml}, 40 \mathrm{ng} / \mathrm{ml}, 60 \mathrm{ng} / \mathrm{ml}, 80 \mathrm{ng} / \mathrm{ml}$, $100 \mathrm{ng} / \mathrm{ml}$ for drug.

All the solution were filtered through $0.2 \mu \mathrm{m}$ membrane filter and injected, chromatograms were recorded at $274 \mathrm{~nm}$ and it was repeated for six times. A calibration graph was plotted between the mean peak area and respective concentration and regression equation was derived.

\section{Fabrication of Drug loaded transdermal films ${ }^{14}$ $17,20,23,24$ :}

The Drug loaded monolithic matrix type transdermal patches were prepared by film casting technique on mercury substrate using different ratios of ERLPO:Methocel K15M, ERSPO:Methocel K15M, Acrylcoat S100:Methocel K15M and Acrylcoat L100:Methocel K15M (1:4,2:3,3:2,4:1) containing drug Metoprolol Tartrate $(15.92 \mathrm{mg} /$ square centimeter patch). The polymers were weighed in requisite ratios keeping the total polymer weight $500 \mathrm{mg}$. Hydrophilic materials i.e. Methocel $\mathrm{K} 15 \mathrm{M}$ was dissolved in water and hydrophobic materials i.e. Eudragit RLPO, Eudragit RLPO, Acrylcoat S100 or Acrylcoat L100 was dissolved in blend of dichloromethane (DCM) and ethanol (50:50). Then both the solution were mixed and stirred on magnetic stirrer to accomplished homogeneous mixture. The above polymeric dispersion was sonicated for 2 minutes to remove entrapped air bubbles. In this study Lipophilic plasticizers DBP \& DBS or hydrophilic plasticizers such as PEG 400 \& Propylene Glycol was added for each polymer combination. 2 different permeation enhancers of Terpene class such as limonene and cineole in different percentage alone and in combination $(2.5 \mathrm{w} / \mathrm{w} \%, 5.0$ w/w $\%, 7.5 \mathrm{w} / \mathrm{w} \%$ or $2.5: 2.5)$ was added to each polymer combination. The resulting solution $(10 \mathrm{ml})$ was poured in a petri dish of $9.2 \mathrm{~cm}$ diameter containing mercury. The rate of evaporation of the solvent was controlled by placing an inverted funnel over the petri dish. The film formation was noted by observing the mercury surface after complete evaporation of the solvent. Aluminium foil was used as backing film and wax paper as release liner (which could be removed before application of the patch on the skin) were applied to complete the TDDS. The patches were cut with a circular metallic die of $2 \mathrm{~cm}$ internal diameter to give an area of $3.14 \mathrm{~cm}^{2}$ and stored in a desiccator until use.

Different formulations were designed further by adding 2 different permeation enhancers of Terpene class such as limonene and cineole in different percentage alone and in combination.

Percentage of Limonene used: $2.5 \mathrm{w} / \mathrm{w} \%, 5.0 \mathrm{w} / \mathrm{w} \%$ and $7.5 \mathrm{w} / \mathrm{w} \%$

Percentage of Cineole used: $2.5 \mathrm{w} / \mathrm{w} \%, 5.0 \mathrm{w} / \mathrm{w} \%$ and $7.5 \mathrm{w} / \mathrm{w} \%$

Combination of Limonene and cineole used (\%): 2.5 w/w $\%: 2.5 \mathrm{w} / \mathrm{w} \%$

16 optimized films were obtained (in optimization step3 ) which were having good and acceptable permeation enhancing capacity across porcine skin. The above optimized films were obtained after considering permeation enhancing capacity via determination of steady state flux, permeation coefficient and enhancement factor. In all the films it was found that combination of permeation enhancers was more effective in comparison to when they were used alone. Hence only combination of permeation enhancers was used for further development of transdermal films and their evaluation.

Table 4: Formulation of Drug loaded transdermal films EM1-EM8

\begin{tabular}{|c|c|c|c|c|c|}
\hline \multirow[t]{2}{*}{$\begin{array}{l}\text { Formulation } \\
\text { code }\end{array}$} & \multirow{2}{*}{$\begin{array}{c}\text { Drug } \\
\text { (mg/ square } \\
\text { centimeter patch) }\end{array}$} & \multirow[t]{2}{*}{ Polymer combination with ratio } & \multirow{2}{*}{$\begin{array}{l}\text { Plasticizer } \\
\text { type and } \\
\text { Percentage }\end{array}$} & \multicolumn{2}{|c|}{$\begin{array}{c}\text { Permeation Enhancer } \\
\text { (\%w/w of polymer) }\end{array}$} \\
\hline & & & & Limonene & Cineole \\
\hline EM1 & 15.92 & ERSPO:METHOCEL K15M(1:4) & PEG 400(20\%) & 2.5 & 2.5 \\
\hline EM2 & 15.92 & ERSPO: METHOCEL K15M(2:3) & PEG $400(20 \%)$ & 2.5 & 2.5 \\
\hline EM3 & 15.92 & ERSPO: METHOCEL K15M (3:2) & DBS $(25 \%)$ & 2.5 & 2.5 \\
\hline EM4 & 15.92 & ERSPO: METHOCEL K15M (4:1) & DBS $(25 \%)$ & 2.5 & 2.5 \\
\hline EM5 & 15.92 & ERLPO: METHOCEL K15M (1:4) & PEG $400(20 \%)$ & 2.5 & 2.5 \\
\hline EM6 & 15.92 & ERLPO: METHOCEL K15M (2:3) & PEG $400(20 \%)$ & 2.5 & 2.5 \\
\hline EM7 & 15.92 & ERLPO: METHOCEL K15M (3:2) & DBS $(25 \%)$ & 2.5 & 2.5 \\
\hline EM8 & 15.92 & ERLPO: METHOCEL K15M(4:1) & DBS $(25 \%)$ & 2.5 & 2.5 \\
\hline
\end{tabular}


Table 5: Formulation of Drug loaded transdermal films AM1-AM8

\begin{tabular}{|c|c|c|c|c|c|}
\hline \multirow{2}{*}{$\begin{array}{c}\text { Formulation } \\
\text { code }\end{array}$} & $\begin{array}{c}\text { Drug } \\
\text { (mg/ square } \\
\text { centimete } \\
\text { patch) }\end{array}$ & Polymer combination with ratio & $\begin{array}{c}\text { Plasticizer } \\
\text { type and } \\
\text { Percentage }\end{array}$ & \multicolumn{2}{|c|}{$\begin{array}{c}\text { Permeation Enhancer } \\
\text { (\%w/w of polymer })\end{array}$} \\
\cline { 5 - 6 } & 15.92 & $\begin{array}{c}\text { ACRYLCOAT S100: } \\
\text { METHOCEL K15M (1:4) }\end{array}$ & PG (15\%) & 2.5 & 2.5 \\
\hline AM1 & 15.92 & $\begin{array}{c}\text { ACRYLCOAT S100: } \\
\text { METHOCEL K15M (2:3) }\end{array}$ & PG (15\%) & 2.5 & 2.5 \\
\hline AM2 & 15.92 & $\begin{array}{c}\text { ACRYLCOAT S100: } \\
\text { METHOCEL K15M (3:2) }\end{array}$ & PG (15\%) & 2.5 & 2.5 \\
\hline AM3 & 15.92 & $\begin{array}{c}\text { ACRYLCOAT S100: } \\
\text { METHOCEL K15M (4:1) }\end{array}$ & DBT (30\%) & 2.5 & 2.5 \\
\hline AM4 & 15.92 & $\begin{array}{c}\text { ACRYLCOAT L100: } \\
\text { METHOCEL K15M (1:4) }\end{array}$ & PG (15\%) & 2.5 & 2.5 \\
\hline AM6 & 15.92 & $\begin{array}{c}\text { ACRYLCOAT L100: } \\
\text { METHOCEL K15M (2:3) }\end{array}$ & PG (15\%) & 2.5 & 2.5 \\
\hline AM7 & 15.92 & $\begin{array}{c}\text { ACRYLCOAT L100: } \\
\text { METHOCEL K15M (3:2) }\end{array}$ & PG (15\%) & 2.5 & 2.5 \\
\hline AM8 & 15.92 & $\begin{array}{c}\text { ACRYLCOAT L100: } \\
\text { METHOCEL K15M (4:1) }\end{array}$ & DBT (30\%) & 2.5 & 2.5 \\
\hline
\end{tabular}

\section{In vivo pharmacokinetic study in Rabbits $9.10,12-14,18-24$}

\section{Study Procedure}

The In vivo pharmacokinetic study will be performed on twelve healthy male albino rabbits weighing between 2.5 to $3.0 \mathrm{~kg}$. The dose of the drug was calculated according to the body surface area of the animal. The rabbits were fasted overnight but water was allowed ad libitum. The rabbits were divided into three groups of four rabbits each. The rabbits were kept in cages with husk bedding. The hair of a dorsal skin surface of around $50.0 \mathrm{~cm}^{2}$ shaved and care taken to avoid skin damage during shaving. On the next morning Group A rabbits orally administered Metoprolol Tartrate $(1.7 \mathrm{mg} / \mathrm{kg}) 2$ times with $0.5-1.0 \mathrm{ml}$ saline by feeding tube at 12 hour interval, Group B rabbits were applied the $1^{\text {st }}$ optimized medicated transdermal patch AM2 to the shaved skin surface of rabbit. Group $\mathbf{C}$ rabbits were applied the $2^{\text {nd }}$ optimized medicated transdermal path EM6 to the shaved skin surface of rabbit. The patches were placed over the skin with the help of surgical adhesive tape. The optimized patches were loaded with same amount of drug as oral.

\section{Sampling}

The blood samples $(1.0 \mathrm{ml})$ withdrawn from the marginal ear vein of the animals. The blood samples were collected at $0.0,0.5,1.0,2.0,4.0,8.0,12,16,20$, and $24 \mathrm{hr}$ and transferred into heparinized test tubes to prevent coagulation of blood. The devices were removed after $24 \mathrm{hr}$ of sampling. The blood samples $(1.0 \mathrm{ml})$ will be extracted and centrifuged. The organic layer will be separated and evaporated under a gentle stream of nitrogen at $45^{\circ} \mathrm{C}$. The residue will be constituted in mobile phase and aliquot injected into the HPLC to determine the drug concentration.

Ethical approval for the handling of experimental animals was obtained from the Institutional Animal Ethical Committee.

\section{In-Vivo Data Analysis}

The plasma concentration of Metoprolol Tartrate at different time intervals was subjected to pharmacokinetic analysis to calculate various parameters: maximum plasma concentration (Cmax), time to reach maximum concentration (Tmax), and area under the plasma concentration-time curve $(\mathrm{AUC} 0 \rightarrow \infty)$. The values of $\mathrm{Cmax}$ and Tmax were read directly from the arithmetic plot of time vs plasma concentration of Metoprolol Tartrate. The AUC was calculated by using the trapezoidal rule. The elimination rate constant $(\mathrm{Ke})$ was calculated by regression analysis from the slope of the line, and the half-life (t1/2) was obtained by $0.693 / \mathrm{Ke}$.

\section{Result and Discussion}

Mobile phase containing plasma was run through the column to obtain peaks for plasma at Rt

2.568 minutes. 


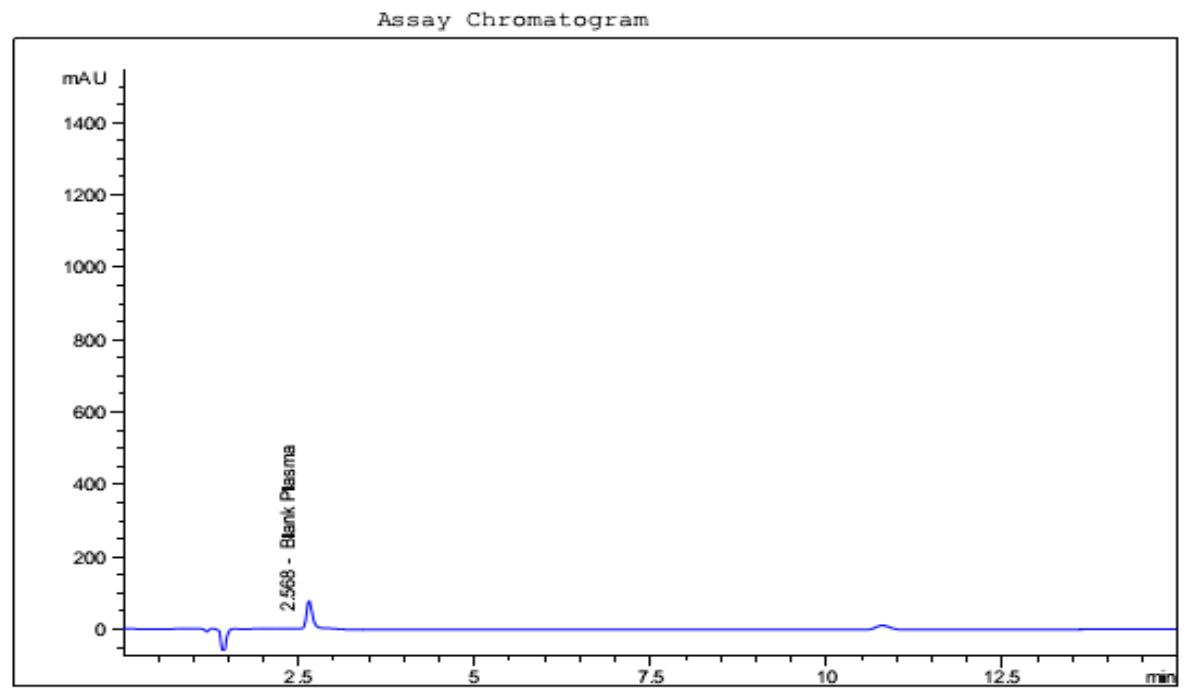

Figure 1: Chromatogram of blank plasma

\section{Standard Curve Graph of Metoprolol in Plasma}

A sample chromatogram of Metoprolol in plasma is shown in fig and Retention time for Metoprolol in plasma was found to be $10.792 \pm 0.001$ minutes.
Standard graph of Metoprolol with plasma was also plotted which shows a linearity range of $20 \mathrm{ng} / \mathrm{ml}$ to 100 $\mathrm{ng} / \mathrm{ml}$ and regression of 0.99 . The data of standard curve for Metoprolol in blood plasma is given in table and figure.

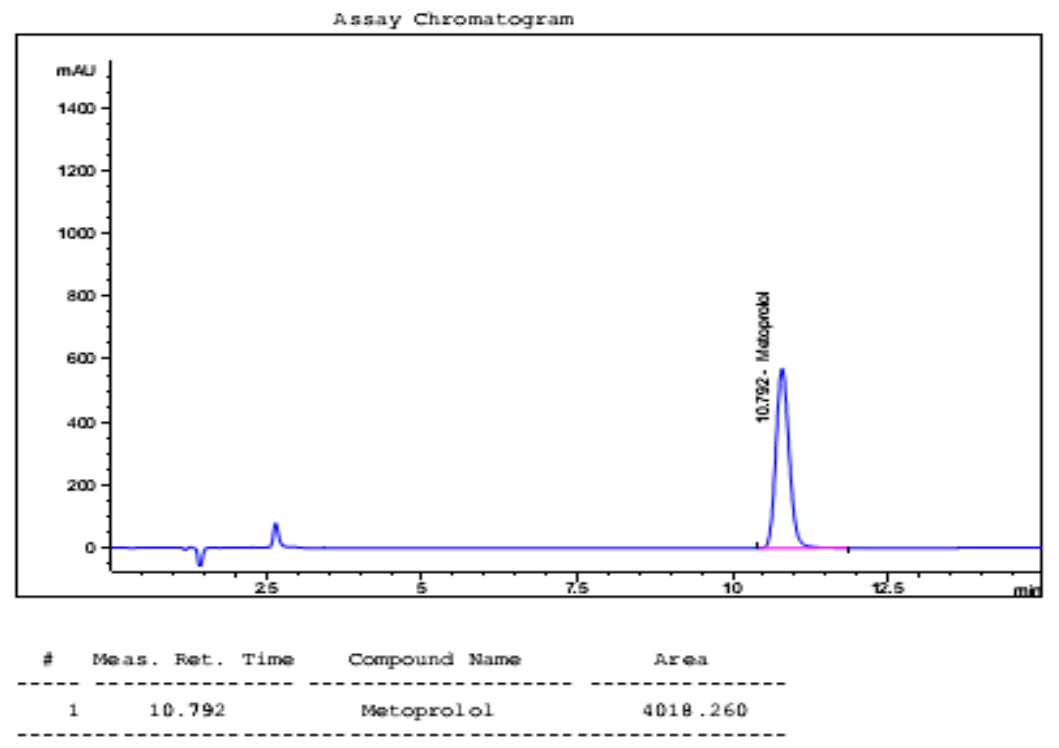

Figure 2: Chromatogram of pure Metoprolol in blood plasma

Table 6: Standard curve of Metoprolol in Plasma

\begin{tabular}{|c|c|c|c|c|c|c|c|}
\hline \multirow{2}{*}{$\begin{array}{l}\text { Standard } \\
\begin{array}{l}\text { Concentration } \\
\text { ng/ml }\end{array}\end{array}$} & \multicolumn{6}{|c|}{ Area under Curve (AUC) at RT (10.792 \pm 0.001 min) } & \multicolumn{1}{c|}{ Mean \pm SD* } \\
\cline { 2 - 8 } & Rep-1 & Rep-2 & Rep-3 & Rep-4 & Rep-5 & Rep-6 & \\
\hline 20 & 855.265 & 854.225 & 868.256 & 856.236 & 860.569 & 848.236 & $857.1311 \pm 6.744395$ \\
\hline 40 & 1605.26 & 1599.27 & 1603.147 & 1612.548 & 1602.258 & 1608.589 & $1605.179 \pm 4.764753$ \\
\hline 60 & 2415.24 & 2412.22 & 2425.16 & 2450.256 & 2415.569 & 2411.254 & $2421.617 \pm 7.660787$ \\
\hline 80 & 3150.27 & 3147.27 & 3145.27 & 3140.548 & 3125.654 & 3150.256 & $3143.211 \pm 9.332913$ \\
\hline 100 & 4018.26 & 4012.25 & 4020.15 & 4015.587 & 4023.547 & 4018.874 & $4018.111 \pm 3.873858$ \\
\hline Correl Coeff $\left(\mathrm{r}^{2}\right)$ & 0.999 & 0.999 & 0.999 & 0.999 & 0.999 & 0.999 & $0.999 \pm 0.00$ \\
\hline Slope $(\mathrm{m})$ & 39.35 & 39.32 & 39.23 & 39.23 & 39.24 & 39.41 & $39.2966 \pm 0.075829$ \\
\hline Intercept $(\mathrm{c})$ & 47.55 & 45.83 & 58.62 & 61.02 & 50.71 & 42.55 & $51.04667 \pm 7.32898$ \\
\hline
\end{tabular}

*Standard deviation 


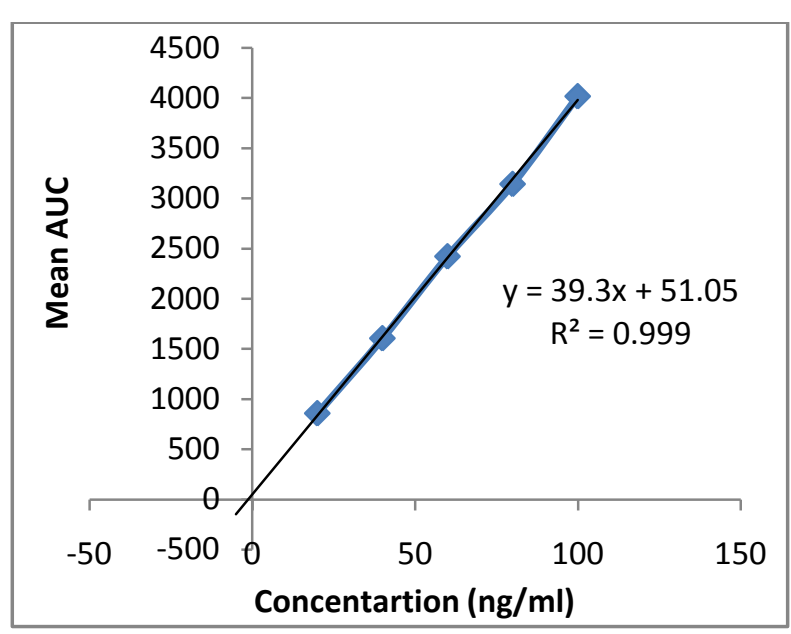

Figure 3: Calibration curve of Metoprolol tartrate
Table 7: HPLC data for pure Metoprolol in rabbit plasma

\begin{tabular}{|l|l|}
\hline Parameter & Rabbit Plasma \\
\hline Retention time (min) & $10.792 \pm 0.001$ \\
\hline Linearity range (ng/ml) & $20-100$ \\
\hline $\mathrm{R}^{2}$ value & 0.999 \\
\hline Equation for linearity & $\mathrm{y}=39.3 \mathrm{x}+51.05$ \\
\hline RSD\% & $0.096-0.7868$ \\
\hline
\end{tabular}

\section{System Suitability Parameters}

Separation variables were set and mobile phase was allowed to saturate the column at $1.00 \mathrm{ml} / \mathrm{min}$. After complete saturation of column, six replicates of working standard of Metoprolol tartrate $100 \mathrm{ng} / \mathrm{ml}$ was injected separately. Peak report and column performance report were recorded for all chromatogram.

Table 8: System Suitability Parameters of Metoprolol

\begin{tabular}{|c|c|c|c|c|c|}
\hline $\begin{array}{c}\text { System suitability } \\
\text { Parameter } \rightarrow\end{array}$ & RT & AUC & $\begin{array}{c}\text { No. of theoretical } \\
\text { plates }\end{array}$ & $\begin{array}{c}\text { Tailing } \\
\text { factor }\end{array}$ & HETP \\
\hline Rep-1 & 10.792 & 4018.26 & 2954 & 1.78 & 0.08463 \\
\hline Rep-2 & 10.793 & 4012.25 & 2953 & 1.77 & 0.08466 \\
\hline Rep-3 & 10.794 & 4020.15 & 2963 & 1.77 & 0.08437 \\
\hline Rep-4 & 10.794 & 4015.587 & 2955 & 1.74 & 0.08460 \\
\hline Rep-5 & 10.792 & 4023.547 & 2952 & 1.78 & 0.08469 \\
\hline Rep-6 & 10.793 & 4018.874 & 2951 & 1.77 & 0.08472 \\
\hline Mean & 10.793 & 4018.111 & 2954.67 & 1.77 & 0.084612 \\
\hline S.D.* & 0.001 & 3.873858 & 4.320 & 0.015 & 0.000126 \\
\hline RSD\%** & 0.009265 & 0.09641 & 0.146 & 0.832 & 0.148637 \\
\hline
\end{tabular}

$* * \%$ Relative Standard deviation *Standard deviation

\section{Validation of Developed Method}

\section{A. Linearity}

Linearity of analytical procedure is its ability (within a given range) to obtain test, which are directly proportional to area of analyte in the sample. The calibration plot was contracted after analysis of five different (from 20 to $100 \mathrm{ng} / \mathrm{ml}$ ) concentrations and areas for each concentration was recorded five times, and mean area was calculated. The regression equation and correlation coefficient of curve are given and the standard calibration curve of the drug is shown in figure. From the mean of AUC observed and respective concentration value, the response ratio (response factor) was found by dividing the AUC with respective concentration (Table 9).

Table 9: Response Ratio Data for Linearity of Metoprolol

\begin{tabular}{|l|c|c|c|}
\hline Replicates & $\begin{array}{c}\text { Concentration } \\
(\mathbf{n g} / \mathbf{m l})\end{array}$ & Mean AUC & Response Ratio \\
\hline Rep-1 & $\mathbf{2 0}$ & 857.131 & 42.85 \\
\hline Rep-2 & $\mathbf{4 0}$ & 1605.179 & 40.12 \\
\hline Rep-3 & $\mathbf{6 0}$ & 2421.617 & 40.36 \\
\hline Rep-4 & $\mathbf{8 0}$ & 3143.211 & 39.29 \\
\hline Rep-5 & $\mathbf{1 0 0}$ & 4018.111 & 40.18 \\
\hline Mean & & 40.56 \\
\hline SD & & 1.344 \\
\hline \% RSD & * Relative Standard deviation *Standard deviation \\
\hline
\end{tabular}




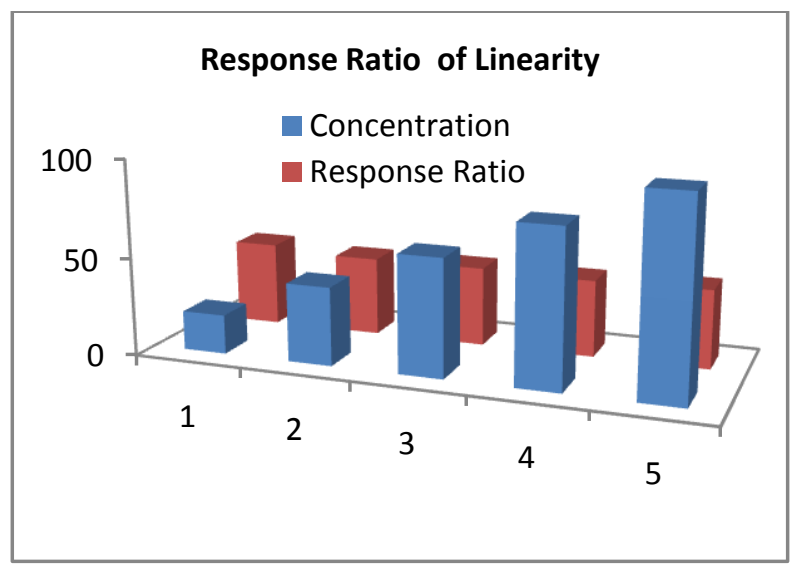

\section{B. Specificity}

Specificity of the method was carried out to assess unequivocally the analyte presence of the components that might be expected to be present, such as impurities, degradation products and matrix components.

\section{Accuracy}

Recovery studies were performed to validate the accuracy of developed method. To pre-analysed sample solution, a definite concentration of standard drug $(80 \%, 100 \%$, and $120 \%)$ was added and then its recovery was analyzed.

Figure 4: 3D Response Ratio Curve of Metoprolol tartrate

Table 10: Recovery Study of Metoprolol (80\% Level)

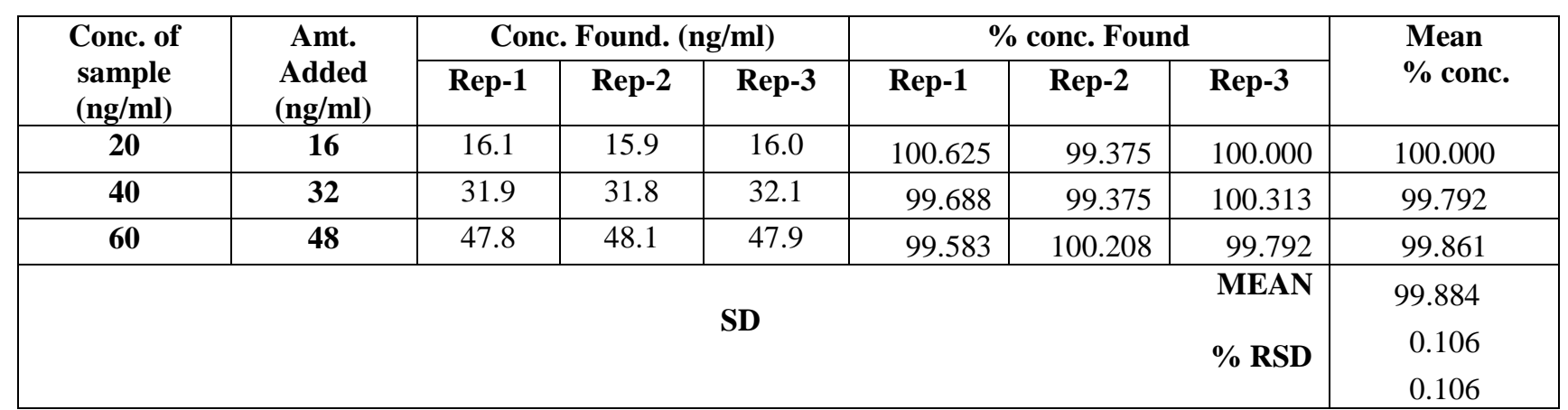

** \% Relative Standard deviation *Standard deviation

Table 11: Recovery Study of Metoprolol (100\% Level)

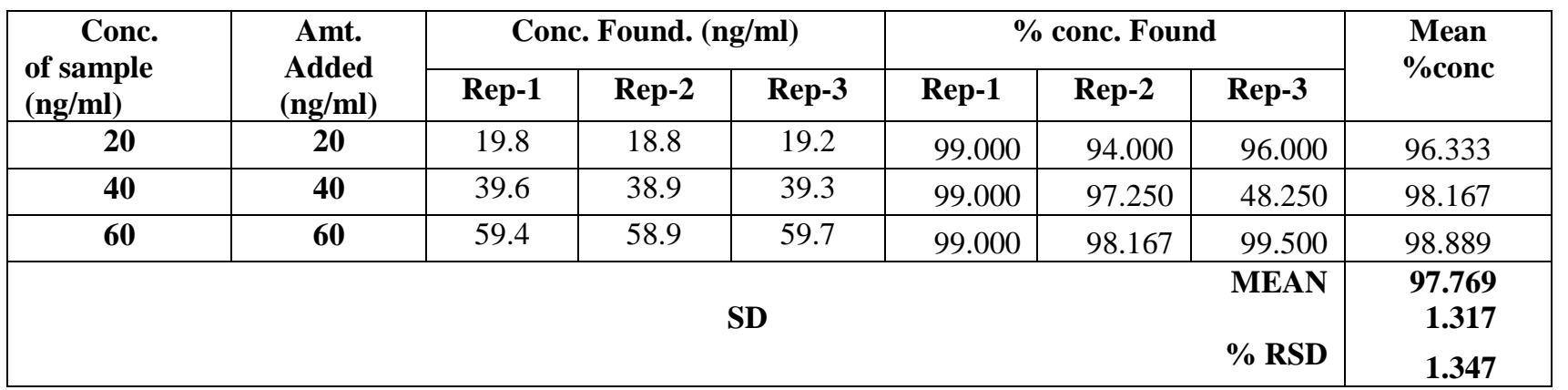

** \% Relative Standard deviation *Standard deviation

Table 12: Recovery Study of Metoprolol (120\% Level)

\begin{tabular}{|c|c|c|c|c|c|c|c|c|}
\hline \multirow{2}{*}{$\begin{array}{c}\text { Conc. } \\
\text { of sample } \\
\text { (ng/ml) }\end{array}$} & \multirow{2}{*}{$\begin{array}{c}\text { Amt. } \\
\text { Added } \\
\text { (ng/ml) }\end{array}$} & \multicolumn{3}{|c|}{ Conc. Found. (ng/ml) } & \multicolumn{3}{|c|}{ \% conc. Found } & \multirow{2}{*}{$\begin{array}{l}\text { Mean } \\
\text { \% conc }\end{array}$} \\
\hline & & Rep-1 & Rep-2 & Rep-3 & Rep-1 & Rep-2 & Rep-3 & \\
\hline 20 & 24 & 24.1 & 23.8 & 23.5 & 100.417 & 99.167 & 97.917 & 99.167 \\
\hline 40 & 48 & 47.8 & 47.9 & 47.5 & 99.583 & 99.792 & 98.958 & 99.444 \\
\hline 60 & 72 & 71.5 & 71.8 & 71.5 & 99.306 & 99.722 & 99.306 & 99.444 \\
\hline & & & & & & & $\begin{array}{r}\text { MEAN } \\
\text { SD } \\
\% \text { RSD }\end{array}$ & $\begin{array}{r}99.352 \\
0.160 \\
0.161\end{array}$ \\
\hline
\end{tabular}

**\% Relative Standard deviation *Standard deviation

\section{Precision}

The precision are established in three differences:

1. Repeatability
2. Intermediate precision

a) Day to Day

b) Analyst to Analyst 
3. Reproducibility

1. Repeatability

The repeatability was performed for five replicate at five concentrations in linearity range 20,40,60, 80 and
$100 \mathrm{ng} / \mathrm{ml}$ for MT indicates the precision under the same operating condition over short interval time. Results of repeatability are reported in tablerespectively.

Table 13: Repeatability of Metoprolol

\begin{tabular}{|c|c|c|c|c|c|c|}
\hline \multirow{2}{*}{ REP. CONC. } & \multicolumn{5}{|c|}{ CONCENTRATION FOUND (ng/ml) } & \multirow[t]{2}{*}{ MEAN } \\
\hline & 20 & 40 & 60 & 80 & 100 & \\
\hline Replicate-1 & 20.9 & 39.1 & 60.2 & 80.2 & 98.9 & \\
\hline Replicate-2 & 21.0 & 39.8 & 59.8 & 79.1 & 100.2 & \\
\hline Replicate-3 & 20.0 & 38.9 & 59.7 & 81.2 & 100.3 & \\
\hline Replicate-4 & 20.2 & 36.7 & 58.7 & 78.9 & 97.3 & \\
\hline Replicate-5 & 20.3 & 37.6 & 59.8 & 78.2 & 97.8 & \\
\hline MEAN & 20.48 & 38.42 & 59.64 & 79.52 & 98.9 & \\
\hline \% MEAN & 102.4 & 96.05 & 99.40 & 99.40 & 98.90 & 99.23 \\
\hline SD & 0.443 & 1.24 & 0.055 & 0.118 & 0.136 & 0.095 \\
\hline \% RSD & 0.043 & 0.129 & 0.056 & 0.118 & 0.137 & 0.097 \\
\hline
\end{tabular}

** \% Relative Standard deviation *Standard deviation

\section{Intermidiate Precision}

\section{a) Day To Day Precision}

Intermediate precision was also performed within laboratory variation on different days in five replicate at five concentrations. Results of day to day intermediate precision for METO reported in table 14respectively.

Table 14: Day-To-Day Variation of Metoprolol

\begin{tabular}{|c|c|c|c|c|c|c|}
\hline \multirow{2}{*}{ REP. } & \multicolumn{5}{|c|}{ CONCENTRATION FOUND (ng/ml) } & \multirow[t]{2}{*}{ MEAN } \\
\hline & 20 & 40 & 60 & 80 & 100 & \\
\hline Replicate-1 & 20.7 & 40.3 & 57.8 & 76.7 & 96.8 & \\
\hline Replicate-2 & 19.2 & 40.3 & 59.9 & 78.8 & 99.3 & \\
\hline Replicate-3 & 19.3 & 38.8 & 58.9 & 75.6 & 99.4 & \\
\hline Replicate-4 & 19.8 & 35.5 & 55.9 & 78.3 & 99.7 & \\
\hline Replicate-5 & 17.8 & 39.8 & 58.3 & 79.8 & 93.9 & \\
\hline MEAN & 193.6 & 38.94 & 58.16 & 77.84 & 97.82 & \\
\hline \% MEAN & 96.8 & 97.35 & 96.93333 & 97.3 & 97.82 & 97.241 \\
\hline SD & 0.105 & 0.202 & 0.149 & 0.168 & 0.248 & 0.174 \\
\hline \% RSD & 0.1090 & 0.2073 & 0.1533 & 0.1727 & 0.2537 & 0.179 \\
\hline
\end{tabular}

** \% Relative Standard deviation $*$ Standard deviation

\section{b) Analyst- To- Analyst Precision}

Analyst to analyst variation was performed by different analyst in five replicate at five concentrations.

Table 15: Analyst- To-Analyst Variation of Metoprolol

\begin{tabular}{|c|c|c|c|c|c|c|}
\hline \multirow{2}{*}{ REP. } & \multicolumn{5}{|c|}{ CONCENTRATION FOUND (ng/ml) } & \multirow[t]{2}{*}{ MEAN } \\
\hline & 20 & 40 & 60 & 80 & 100 & \\
\hline Replicate-1 & 18.1 & 38.2 & 59.41 & 80.3 & 99.8 & \\
\hline Replicate-2 & 18.2 & 38.9 & 59.32 & 77.9 & 99.9 & \\
\hline Replicate-3 & 18.3 & 38.1 & 59.01 & 78.9 & 98.3 & \\
\hline Replicate-4 & 16.1 & 37.3 & 60.31 & 77.2 & 95.8 & \\
\hline Replicate-5 & 22.3 & 40.3 & 60.20 & 78.8 & 98.8 & \\
\hline MEAN & 18.6 & 38.56 & 59.65 & 78.62 & 98.52 & \\
\hline$\%$ MEAN & 93 & 96.4 & 99.41667 & 98.275 & 98.52 & 97.122 \\
\hline SD & 0.226 & 0.113 & 0.057 & 0.117 & 0.166 & 0.136 \\
\hline$\% \mathrm{RSD}$ & 0.2431 & 0.1168 & 0.0577 & 0.1190 & 0.1688 & 0.141 \\
\hline
\end{tabular}

** \% Relative Standard deviation $*$ Standard deviation 


\section{Reproducibility}

The reproducibility was performed by chemical to chemical (use of rankem chemicals in place of merck chemicals) variation in five replicate at five concentrations.

Table 16: Reproducibility of Metoprolol

\begin{tabular}{|c|c|c|c|c|c|c|}
\hline \multirow{2}{*}{ REP. } & \multicolumn{4}{|c|}{ CONCENTRATION FOUND (ng/ml) } & MEAN \\
\cline { 2 - 7 } & $\mathbf{2 0}$ & $\mathbf{4 0}$ & $\mathbf{6 0}$ & $\mathbf{8 0}$ & $\mathbf{1 0 0}$ \\
\hline Replicate-1 & 19.1 & 39.2 & 59.4 & 78.9 & 99.6 \\
\hline Replicate-2 & 18.7 & 39.4 & 57.9 & 79.3 & 98.9 \\
\hline Replicate-3 & 19.4 & 39.3 & 58.7 & 78.3 & 97.8 \\
\hline Replicate-4 & 18.5 & 36.7 & 59.1 & 78.9 & 96.9 \\
\hline Replicate-5 & 19.7 & 38.6 & 58.9 & 79.9 & 97.9 \\
\hline MEAN & 19.08 & 38.64 & 58.80 & 79.06 & 98.22 & \\
\hline \% MEAN & 95.400 & 96.600 & 98.000 & 98.825 & 98.220 & $\mathbf{9 7 . 4 0 9}$ \\
\hline SD & 0.049 & 0.113 & 0.057 & 0.059 & 0.105 & $\mathbf{0 . 0 7 6}$ \\
\hline \% RSD & 0.052 & 0.117 & 0.058 & 0.060 & 0.107 & $\mathbf{0 . 0 7 8}$ \\
\hline
\end{tabular}

** \% Relative Standard deviation *Standard deviation

\section{Robustness}

As per ICH norms, small, but deliberate variations in concentration of the mobile phase were made to check the method's capacity to remain unaffected. The ratio of mobile phase was change from, ACN: Methanol: Ammonium Acetate Buffer pH- 5 (25:55:20 \% V/V/V), to $(25: 54: 21 \% \mathrm{~V} / \mathrm{V} / \mathrm{V})$. Results of robustness are reported in table-

Table 17: Robustness of Metoprolol

\begin{tabular}{|c|c|c|c|c|c|c|}
\hline \multirow{2}{*}{ REP. CONC. } & \multicolumn{5}{|c|}{ CONCENTRATION FOUND (ng/ml) } & MEAN \\
\cline { 2 - 7 } & $\mathbf{2 0}$ & $\mathbf{4 0}$ & $\mathbf{6 0}$ & $\mathbf{8 0}$ & $\mathbf{1 0 0}$ & 99.2 \\
\hline Replicate-1 & 18.9 & 38.9 & 59.8 & 87.7 & 99.2 \\
\hline Replicate-2 & 18.4 & 39.9 & 57.4 & 88.9 & 99.6 \\
\hline Replicate-3 & 19.3 & 37.3 & 58.3 & 87.9 & 99.5 \\
\hline Replicate-4 & 18.3 & 36.7 & 58.9 & 89.5 & 99.3 \\
\hline Replicate-5 & 19.9 & 37.3 & 53.4 & 88.9 & 99.36 & 99.360 \\
\hline MEAN & 19.14 & 38.02 & 57.56 & 78.64 & $\mathbf{9 6 . 8 6 9}$ \\
\hline \% MEAN & 95.700 & 95.050 & 95.933 & 98.300 & 0.018 & $\mathbf{0 . 1 0 5}$ \\
\hline SD & 0.048 & 0.133 & 0.248 & 0.080 & 0.018 & $\mathbf{0 . 1 1 0}$ \\
\hline * RSD & 0.050 & 0.140 & 0.259 & 0.081 & &
\end{tabular}

\section{a. Detection Limit and Quantitation Limit}

The LOD and LOQ of developed method was calculated based on the standard deviation of response and slope of the linearity curve. (Table 18)

Table 18: LOD and LOQ of Metoprolol

\begin{tabular}{|c|c|c|}
\hline Name & LOD $(\mathbf{n g} / \mathbf{m l}) \pm$ SD $*$ & LOQ $(\mathbf{n g} / \mathbf{m l}) \pm$ SD $*$ \\
\hline Metoprolol Tartrate & $5.8 \pm 0.005$ & $16.1 \pm 0.003$ \\
\hline
\end{tabular}

\section{*Standard deviation}

\section{Plasma Estimation of Metoprolol in Rabbits}

The plasma concentrations of MT vs. time are shown in Fig. and the pharmacokinetic parameters are presented in Table. The $\mathrm{C}_{\max }$ and $\mathrm{t}_{\max }$ after oral administration of MT were $94.24 \pm 0.19 \mathrm{ng} / \mathrm{ml}$ and $2.000 \pm 0.00 \mathrm{~h}$, respectively. In case of transdermal patches, the $C_{\max }$ $(91.160 \pm 0.16$ to $93.160 \pm 0.13 \mathrm{ng} / \mathrm{ml})$ and $\mathrm{t}_{\max }(8 \mathrm{~h})$ values were significantly different compared to oral route. Measurable concentrations of the drug were obtained within an hour of application of the patch and relatively steady plasma concentration of drug was observed for over $24 \mathrm{~h}$. The biological half-life $\left(t_{1 / 2}\right)$ of MT was prolonged to about $6 \mathrm{~h}$ (oral: $2.419 \pm 1.02 \mathrm{~h}$ ) in Rabbits. 
Table 19: Plasma Estimation of Metoprolol in Rabbits

\begin{tabular}{|c|c|c|c|}
\hline \multirow{2}{*}{$\begin{array}{l}\text { Time } \\
\text { (hrs) }\end{array}$} & \multicolumn{3}{|c|}{ Drug concentration in blood plasma (ng/ml) } \\
\hline & $\begin{array}{c}\text { Pure Drug } \\
\text { administered orally }\end{array}$ & $\begin{array}{c}\text { Optimized Transdermal } \\
\text { film AM2* }\end{array}$ & $\begin{array}{c}\text { Optimized Transdermal film } \\
\text { EM6* }\end{array}$ \\
\hline 0 & 0 & 0 & 0 \\
\hline 0.5 & $46.21 \pm 1.23$ & $17.73 \pm 2.31$ & $19.15 \pm 2.26$ \\
\hline 1 & $68.44 \pm 1.55$ & $36.11 \pm 2.11$ & $38.59 \pm 2.42$ \\
\hline 2 & $94.24 \pm 1.20$ & $45.62 \pm 2.51$ & $48.17 \pm 2.12$ \\
\hline 4 & $51.51 \pm 1.77$ & $61.77 \pm 1.52$ & $64.53 \pm 2.31$ \\
\hline 6 & $32.11 \pm 2.31$ & $83.82 \pm 1.44$ & $85.33 \pm 1.71$ \\
\hline 8 & $19.43 \pm 1.11$ & $91.16 \pm 1.91$ & $93.15 \pm 1.46$ \\
\hline 12 & $5.12 \pm 1.81$ & $90.23 \pm 1.43$ & $91.32 \pm 1.21$ \\
\hline 14 & $93.14 \pm 1.41$ & $87.41 \pm 1.22$ & $90.55 \pm 1.20$ \\
\hline 18 & $41.25 \pm 1.09$ & $82.52 \pm 1.81$ & $88.13 \pm 2.51$ \\
\hline 20 & $22.31 \pm 1.33$ & $63.79 \pm 1.55$ & $71.44 \pm 2.09$ \\
\hline 24 & $8.77 \pm 2.45$ & $41.76 \pm 1.91$ & $44.11 \pm 2.31$ \\
\hline
\end{tabular}

*Significant compared to MT-Oral ( $p<0.05)$; each point represents Mean $\pm S E ; n=3$

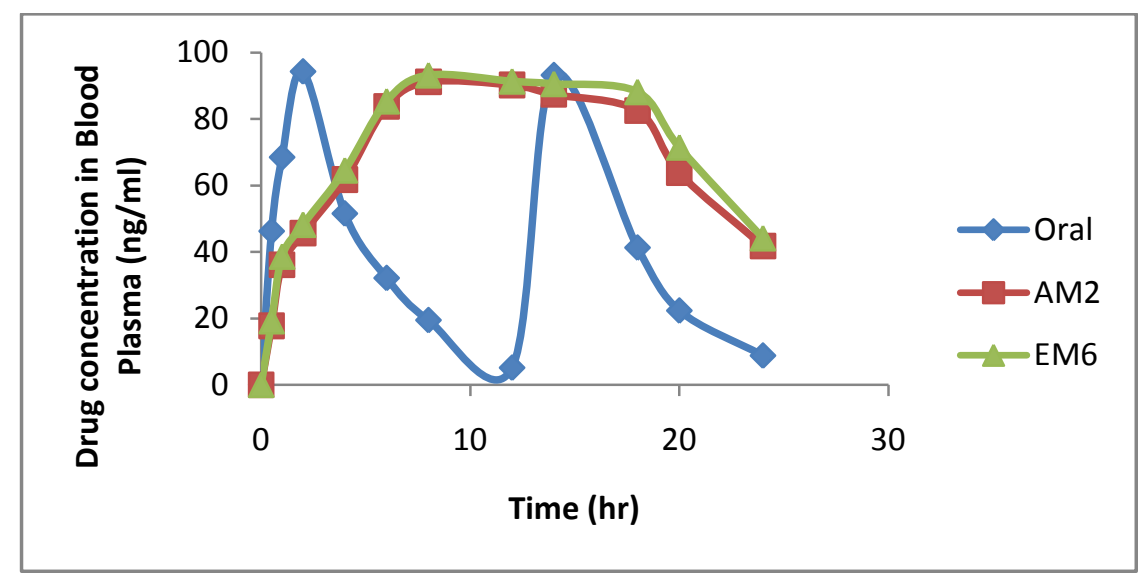

Figure 5: Plasma concentration-time profile of MT after oral and transdermal patch treatment in Rabbits

Table 20: Pharmacokinetic parameters after oral and transdermal treatment of MT

\begin{tabular}{|c|c|c|c|c|}
\hline S.No. & $\begin{array}{c}\text { Pharmacokinetic } \\
\text { parameter }\end{array}$ & $\begin{array}{c}\text { Pure metoprolol administered } \\
\text { orally }\end{array}$ & $\begin{array}{c}\text { Optimized } \\
\text { formulation AM2 }\end{array}$ & $\begin{array}{c}\text { Optimized } \\
\text { formulation EM6 }\end{array}$ \\
\hline 1 & $\mathrm{t}_{1 / 2}(\mathrm{hr})$ & $2.419 \pm 1.02$ & $6.165 \pm 0.15^{*}$ & $5.970 \pm 0.13^{*}$ \\
\hline 2 & $\mathrm{Ke}\left(\mathrm{h}^{-1}\right)$ & $0.2864 \pm 0.003$ & $0.112 \pm 0.002^{*}$ & $0.116 \pm 0.002^{*}$ \\
\hline 3 & $\mathrm{~T}_{\max }(\mathrm{hr})$ & $2.000 \pm 0.00$ & $8.000 \pm 0.00^{*}$ & $8.000 \pm 0.00^{*}$ \\
\hline 4 & $\mathrm{C}_{\max }(\mathrm{ng} / \mathrm{ml})$ & $94.24 \pm 0.19$ & $91.160 \pm 0.16^{*}$ & $93.160 \pm 0.13^{*}$ \\
\hline 5 & $\mathrm{AUC}_{0-\mathrm{t}}\left(\mathrm{ng} / \mathrm{ml} \mathrm{H}^{*} \mathrm{~h}\right)$ & $451.565 \pm 4.22$ & $1726.408 \pm 4.61^{*}$ & $1805.513 \pm 4.35^{*}$ \\
\hline 6 & $\mathrm{AUC}_{0-\infty}\left(\mathrm{ng} / \mathrm{ml}{ }^{*} \mathrm{~h}\right)$ & $469.439 \pm 4.19$ & $2097.836 \pm 4.43^{*}$ & $2185.458 \pm 4.11^{*}$ \\
\hline 7 & $\mathrm{AUMC}_{0-\infty}\left(\mathrm{ng} / \mathrm{ml}^{*} \mathrm{~h}^{2}\right)$ & $2009.104 \pm 6.03$ & $33282.570 \pm 6.21^{*}$ & $34600.480 \pm 6.12^{*}$ \\
\hline 8 & $\mathrm{MRT}(\mathrm{hr})$ & $4.279 \pm 1.23$ & $15.865 \pm 0.32^{*}$ & $15.832 \pm 0.41^{*}$ \\
\hline
\end{tabular}

All values are expressed as Mean $\pm S E, n=3$

$\mathrm{C}_{\max }=$ Maximum concentration; $\mathrm{t}_{\max }=$ Time of maximum concentration; $\mathrm{K}_{\mathrm{e}}=$ Elimination rate constant; AUC=Area under plasma concentration-time curve; $\mathrm{AUMC}=$ Area under plasma First Moment concentration-time curve; $\mathrm{t}_{1 / 2}=$ Elimination half-life; MRT=Mean residential time,

*Significant compared to oral MT $(\mathrm{p}<0.05)$

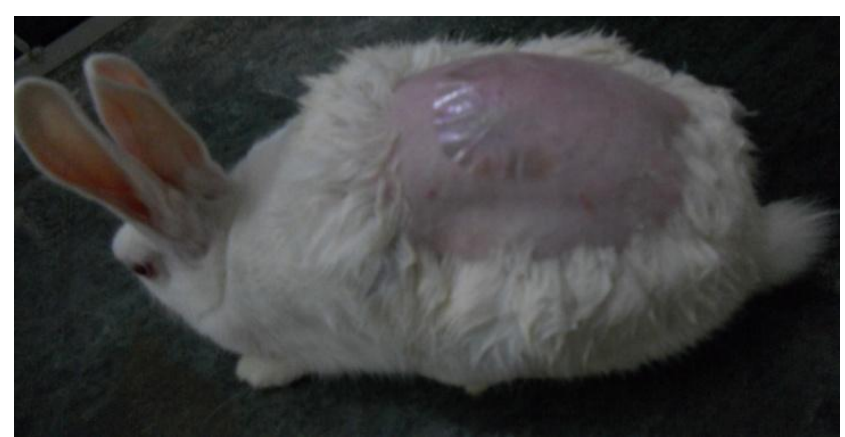

Figure 6: Application of Optimized Transdermal Patches 


\section{CONCLUSION:}

A simple, rapid, reproducible, and sensitive HPLC method has been developed for analysis of MT in human plasma. The pharmacokinetic parameters obtained with transdermal patches were significantly $(\mathrm{p}<0.05)$ different from those obtained with oral administration. The In vivo pharmacokinetic results from the oral administration of drug metoprolol tartrate solution indicate that the drug is rapidly absorbed from the rabbit GI tract, whereas drugs through transdermal route are slowly but continuously absorbed. Though the rise in drug concentration was slower than oral administration, the drug concentration in plasma remained high for longer period with transdermal patches. The calculated pharmacokinetic parameters indicate that the biological half life $\left(t_{1 / 2}\right)$ of drug is prolonged in rabbits by transdermal application in comparison to oral dose. Hence, the drug administered through transdermal patch will remain for longer period of time in the body and thus exert a sustained the action. Moreover, the improved performance of the designed

\section{REFERENCES:}

1. Florey K, Editor. Analytical Profiles of Drug Substances Vol. 12. New York: Academic Press; 1983

2. Sweetman SC. editor. Martindale: The Complete Drug Reference. London: The Pharmaceutical Press; 1999,p.1338

3. Holford NHG editor. In: Katzung B. G., Lange, Basic \& Clinical Pharmacology, New York: McGraw-Hill; 2004,p. 3450

4. Indian Pharmacopoeia, Vol. II $^{\text {nd }}$, Ghaziabad: Indian Pharmacopoeia Commission; Government of India, Ministry of Health \& Family Welfare.; 2007, P.763

5. Goodman and Gilman's "The Pharmacology Basis of Therapeutics", Medical publishing Division, New York, 2001, 249- 260.

6. Available from http://www.rxlist.com/lopressor-drug

7. Chien YW. Transdermal therapeutic systems. In: Robinson JR, Lee V. H. editors. Controlled drug delivery: Fundamentals and applications. New York: Marcel Dekker; 1987, p. 524-549.

8. Chien YW. Novel drug delivery systems. New York: Informa Healthcare; 1992.

9. Yoon IS, Choi MK, Kim JS, Shim CK et al. Pharmacokinetics and first-pass elimination of metoprolol in rats: contribution of intestinal first-pass extraction to low bioavailability of metoprolol, Xenobiotica 2011; 41(3): 243-251

10. Aqil M, Sultana Y, Sahaz N. Comparative Bioavailability of Metoprolol Tartrate after Oral and Transdermal Administration in Healthy Male Volunteers 2007; Clin Drug Invest, 27 (12): 833-839

11. Yilmaz B, Asci A, Arslan S. Determination of metoprolol in human plasma and urine by high-performance liquid chromatography with fluorescence detection. J Sep Sci. 2010 Jul;33(13):1904-8.

12. Johnston GD, Nies AS, Gal J.Determination of metoprolol in human blood plasma using high-performance liquid chromatography. J Chromatogr. 1983 Nov 11; 278(1):204-8.

13. Bühring KU, Garbe A. Determination of the new beta-blocker bisoprolol and of metoprolol, atenolol and propranolol in plasma and urine by high-performance liquid chromatography. J Chromatogr. 1986 Oct 31; 382:215-24.

14. Baviskar DT, Parik VB, Jain DJ. Development of Matrix-type transdermal delivery of lornoxicam: in vitro evaluation and optimized transdermal films of drug is also reflected by area under the curve (AUC) measurement as no trough and peaks in drug plasma level was recorded. The high AUC values observed with the patches also indicate increased bioavailability of the drug, this may be due to bypass of the hepatic first pass effects and avoidance from gastric degradation. The $\mathrm{T}_{\max }$ value was considerably high. Maximum plasma concentration $\left(\mathrm{C}_{\max }\right)$ of the optimized transdermal films was found to be less in comparison to oral dose. The significantly less elimination rate constant $(\mathrm{Ke})$ and high mean residence time (MRT) values of drug by transdermal application in comparison to oral dose, further supports the sustained action of the drug from transdermal patches.

On the whole, transdermal patches of MT showed better in vivo effectiveness in rabbits compared to oral administration. This could be due to slow and continuous supply of drug at a desirable rate to systemic circulation, which could better control the hypertension in hypertensive subjects.

pharmacodynamic and pharmacokinetic studies in albino rats.PDA J Pharm Sci Technol. 2013 Jan-Feb; 67(1):9-22

15. Kshirsagar SJ, Bhalekar MR, Mohapatra SK, Development and evaluation of carvedilol-loaded transdermal drug delivery system: In-vitro and in-vivo characterization study. Drug Dev Ind Pharm. 2012 Dec; 38(12):1530-7.

16. Ali A, Trehan A, Ullah Z, Aqil M. Matrix type transdermal therapeutic systems of glibenclamide: Formulation, ex vivo and in vivo characterization. Drug Discoveries \& Therapeutics 2011; 5(1):53-59.

17. Agrawal SS, Pruthi JK. Development and evaluation of matrix type transdermal patch of ethinylestradiol and medroxyprogesterone acetate for anti-implantation activity in female Wistar rats, Contraception 2011; 84(5):533-538

18. Kress HG, Boss H, Delvin T, Lahu G. et al. Transdermal fentanyl matrix patches Matrifen and Durogesic DTrans are bioequivalent., European Journal of Pharmaceutics and Biopharmaceutics 2010; 75: 225-231

19. Shams MS, Alam MI, Sultana Y, M. Aqil. et al. Pharmacodynamics of a losartan transdermal system for the treatment of hypertension Losartan transdermal system Drug Development and Industrial Pharmacy 2010; 36(4): 385-392

20. Chandak AR, Verma PRP. Eudragit-based transdermal delivery system of pentazocine: Physico-chemical, in vitro and in vivo evaluations Pharmaceutical Development and Technology 2010; 15(3): 296-304

21. Agrawal SS, Aggarwal A. Randomised, cross-over, comparative bioavailability trial of matrix type transdermal drug delivery system (TDDS) of carvedilol and hydrochlorothiazide combination in healthy human volunteers: A pilot study. Contemporary Clinical Trials 2010; 31: 272-278

22. El-Laithy HM. Novel transdermal delivery of Timolol maleate using sugar esters: Preclinical and clinical studies. European Journal of Pharmaceutics and Biopharmaceutics 2009;72: 239-245

23. Ubaidulla U, Reddy MVS, Ruckmani, Khar RK. Transdermal Therapeutic System of Carvedilol: Effect of Hydrophilic and Hydrophobic Matrix on In Vitro and In Vivo Characteristics, AAPS Pharm Sci Tech 2007; 8(1): E1-E8

24. Mutalik S, Udupa N, Kumar S, Agarwal S et al. Glipizide matrix transdermal systems for diabetes mellitus: Preparation, in vitro and preclinical studies Life Sciences 2006,79 15681577. 